\title{
Association between single nucleotide polymorphisms of the osteoprotegerin gene and postmenopausal osteoporosis in Chinese women
}

\author{
J.F. Song, Z.Z. Jing, W. Hu and Y.X. Su \\ Department of Orthopaedics, Shanxi Provincial People's Hospital, Taiyuan, \\ Shanxi Province, China \\ Corresponding author: J.F. Song \\ E-mail: jiefu_song@sina.com
}

Genet. Mol. Res. 12 (3): 3279-3285 (2013)

Received January 25, 2013

Accepted March 16, 2013

Published September 3, 2013

DOI http://dx.doi.org/10.4238/2013.September.3.4

\begin{abstract}
Osteoporosis is an important and common complex health problem, particularly in postmenopausal women. It is characterized by a reduction in bone mineral density (BMD) and a deterioration of bone microarchitecture with a consequent increase of fracture risk. The osteoprotegerin $(O P G)$ gene is considered to play an important role in the pathogenesis of osteoporosis. We analyzed SNPs of the $O P G$ gene and associations between these polymorphisms and BMD in 399 Chinese postmenopausal women. BMD was quantified at the lumbar spine $\left(\mathrm{L}_{2-4}\right)$, femoral neck, and total hip. The g.2264T $>\mathrm{C}$ and g.27676A $>\mathrm{C}$ SNPs were detected by PCR-RFLP and DNA sequencing methods. A significant association with spine BMD was found for g.27676A $>$ C. The spine BMD value for subjects with genotype AA was significantly higher than those with genotypes GA and AA. No significant association was detected between any of the SNP marker genotypes and the other traits. We conclude that g.27676A $>\mathrm{C}$ in the $O P G$ gene affects spine BMD and
\end{abstract}


that the $\mathrm{C}$ allele is associated with increased risk for osteoporosis in Chinese postmenopausal women.

Key words: Association analysis; Bone mineral density; Osteoporosis; Single nucleotide polymorphisms; Postmenopausal women;

Osteoprotegerin gene

\section{INTRODUCTION}

Osteoporosis, a common complex and polygenic health problem of the postmenopausal women, is a skeletal disorder characterized by a reduction in bone mineral density (BMD) and a microarchitectural deterioration of bone tissue with a consequent increase in fracture risk (Cummings et al., 1985; Riggs and Melton, 1986, Peck, 1993; Kanis et al., 1994; Geng et al., 2007; Garcia-Unzueta et al., 2008). BMD is a complex trait that is influenced by multiple genes and environmental factors (Ohmori et al., 2002). Genetic factors play an important role in the pathogenesis of osteoporosis (Albagha and Ralston, 2006; Ferrari, 2008; Cheung et al., 2010; Hosoi, 2010; Ralston, 2010). Several genes have been found to be involved in bone mineral homeostasis, bone remodeling, and bone matrix composition, e.g., osteoprotegerin $(O P G)$ (Pocock et al., 1987; Hofbauer and Schoppet, 2002; Langdahl et al., 2002; Yamada et al., 2003; Arko et al., 2002, 2005; Vidal et al., 2011), estrogen receptor (Ioannidis et al., 2002, 2004; Gennari et al., 2005), vitamin D receptor (Fang et al., 2005; Li et al., 2012), transforming growth factor b1 (Yamada, 2001), and collagen type 1a1 (Mann and Ralston, 2003). OPG has been considered an important candidate gene for osteoporosis, as polymorphisms in $O P G$ may contribute to a genetic influence on BMD (Pocock et al., 1987; Hofbauer and Schoppet, 2002; Langdahl et al., 2002; Yamada et al., 2003; Arko et al., 2002, 2005; Vidal et al., 2011). Association analyses between $O P G$ polymorphisms and BMD have been performed in osteoporosis, e.g., A163G, T245G, T950C, and G1181C (Arko et al., 2002; Langdahl et al., 2002; Ohmori et al., 2002; Jorgensen et al., 2004; Zhao et al., 2005; Kim et al., 2007; Ueland et al., 2007; Garcia-Unzueta et al., 2008; Moffett et al., 2008; Lee et al., 2010), but there have been no published results about the association between the g.2264T $>\mathrm{C}$ and g.27676A $>$ C polymorphisms of the $O P G$ gene and BMD in various subjects. Therefore, the objective of this study was to investigate the g.2264 T $>$ C and g.27676A $>$ C polymorphisms of the $O P G$ gene and to evaluate their effect on BMD in Chinese women.

\section{MATERIAL AND METHODS}

\section{Subjects}

The study included 399 postmenopausal women, where 247 were primary postmenopausal osteoporosis patients (aged 49-80 years) and 152 were healthy volunteers (aged 48-81 years). Subjects suffering from diseases or taking drugs that could affect bone metabolism were excluded. All subjects were genetically unrelated ethnic Han Chinese. This study was approved by the local Ethics Committee, and informed consent was obtained from all participants. 


\section{Measurement of bone mineral density}

BMD of the lumbar spine $\left(\mathrm{L}_{2-4}\right)$, femoral neck, and total hip was assessed using dualenergy X-ray absorptiometry (Lunar Expert 1313, Lunar Corp., USA). BMD was automatically calculated from the bone mineral content $(\mathrm{g})$ and bone area $\left(\mathrm{cm}^{2}\right)$ and expressed absolutely in $\mathrm{g} / \mathrm{cm}^{2}$.

\section{Genotyping test}

Genomic DNA was isolated from peripheral venous blood samples according to the standard phenol/chloroform/isoamyl alcohol extraction protocol and stored at $-20^{\circ} \mathrm{C}$ until analyzed. Based on the DNA sequences (GenBank ID: NG_012202.1) and mRNA sequences (GenBank ID: NM_002546.3) of the human $O P G$ gene, 2 pairs of primers were designed using the Primer Premier 5.0 software (Premier Biosoft International, Palo Alto, CA, USA) to amplify and verify candidate SNPs (Table 1). Primer sequences, annealing temperature, region, fragment sizes, and selected restriction enzymes are shown in Table 1. Polymerase chain reaction (PCR) amplifications were performed in a $20-\mu \mathrm{L}$ reaction mixture containing $50 \mathrm{ng}$ mixed DNA template, $10 \mathrm{pM}$ each primer, $0.20 \mathrm{mM}$ dNTPs, $2.5 \mathrm{mM} \mathrm{MgCl}$, and $0.5 \mathrm{U}$ Taq DNA polymerase (TaKaRa, Dalian, China). The PCR protocol was $95^{\circ} \mathrm{C}$ for 5 min followed by 32 cycles of $94^{\circ} \mathrm{C}$ for $30 \mathrm{~s}$, annealing at the corresponding temperature (shown in Table 1) for $30 \mathrm{~s}$, and $72^{\circ} \mathrm{C}$ for $30 \mathrm{~s}$, with a final extension at $72^{\circ} \mathrm{C}$ for $10 \mathrm{~min}$. The PCR products were separated on a $1.5 \%$ agarose gel (Promega) including $0.5 \mu \mathrm{g} / \mathrm{mL}$ ethidium bromide. The g.2264T $>\mathrm{C}$ and g.27676A $>$ C SNPs were genotyped by the PCR-restriction fragment length polymorphism (PCR-RFLP) method. Aliquots of $5 \mu \mathrm{L}$ PCR products were digested with $2 \mathrm{U}$ restriction enzyme at $37^{\circ} \mathrm{C}$ for $10 \mathrm{~h}$ following the supplier manual. The digested products were separated by electrophoresis for $1 \mathrm{~h}$ at $100 \mathrm{~V}$ on a $2.5 \%$ agarose gel stained with ethidium bromide in $1 \mathrm{X}$ TAE buffer. The genotype results of allelic variation were based on the electrophoretic pattern of the restriction enzyme-treated PCR products. The PCR-amplified products of each genotype were purified using a Wizard Prep PCR purification kit and were sequenced in both directions with an ABI 3730 sequencer (Bioasia Biotechnology Co., Ltd., Shanghai, China).

\begin{tabular}{|c|c|c|c|c|c|c|}
\hline SNPs & Primer sequences & AT $\left({ }^{\circ} \mathrm{C}\right)$ & SAF (bp) & Region & $\mathrm{RE}$ & RES (genotype: bp) \\
\hline g.2264T $>C$ & $\begin{array}{l}\text { 5'-TATCTGTGGTGCTTCTAGTTCC-3' } \\
\text { 5'-GATGATACAGCATTATCAGAAGAT-3' }\end{array}$ & 54.0 & 216 & Intron 1 & NlaIII & $\begin{array}{l}\text { TT: } 216 \\
\text { TC: } 216,150,66 \\
\text { CC: } 150,66\end{array}$ \\
\hline g. $27676 \mathrm{~A}>\mathrm{C}$ & $\begin{array}{l}\text { 5'-TGTACATTGTGAAGCTGTGAAGG-3' } \\
\text { 5'-AAGTGGGAGCAGAAGACATTG-3' }\end{array}$ & 58.0 & 219 & Exon 5 & AvaII & $\begin{array}{l}\text { AA: } 219 \\
\text { AC: } 219,197,22 \\
\text { CC: } 197,22\end{array}$ \\
\hline
\end{tabular}

$\mathrm{AT}=$ annealing temperature; $\mathrm{SAF}=$ size of amplification fragment; $\mathrm{RE}=$ restriction enzyme; RES $=$ size of fragments at the indicated allele after digestion of the PCR product using the respective restriction enzyme.

\section{Statistical analysis}

Allelic and genotypic frequencies in the subjects studied were calculated and the Har- 
dy-Weinberg equilibrium of the mutation was determined by the chi-squared test. Quantitative data were compared by one-way ANOVA and the LSD post hoc test. Multiple regression and logistic regression analyses were carried out to evaluate the relationships between the variables. All data are reported as means \pm SD. All statistical analyses were performed with the Statistical Package for Social Sciences software (SPSS, Windows version release 15.0; SPSS Inc., Chicago, IL, USA). $\mathrm{P}<0.05$ was considered to be statistically significant.

\section{RESULTS}

\section{SNP identification and genotyping}

In this study, the g.2264T $>C$ and g.27676A $>C$ SNPs were identified by PCR-RFLP and DNA sequencing methods, including $\mathrm{T} \rightarrow \mathrm{C}$ mutation at position 2264 and $\mathrm{A} \rightarrow \mathrm{C}$ mutation [resulting in phenylalanine (Phe) to valine (Val) amino acid replacement, p.Phe371Val] at position 27676 of the human $O P G$ gene, respectively, in intron 1 and exon 5 (reference sequences NG_012202.1, NM_002546.3, and NP_002537.3). The PCR product of g.2264T >C was digested with NlaIII enzyme and divided into 3 genotypes, TT (216 bp), TC (216, 150, and $66 \mathrm{bp}$ ), and CC (150 and $66 \mathrm{bp}$ ) (Table 1). The PCR product of g.27676 A $>\mathrm{C}$ was digested with the AvaII enzyme, and the 3 possible genotypes were defined by 3 distinct banding patterns: AA (219 bp), AB (219, 197, and 22 bp), and BB (197 and 22 bp) (Table 1).

\section{Frequencies of allele and genotype}

The allelic and genotypic frequencies of the g.2264T $>C$ and g.27676A $>C$ polymorphisms are shown in Table 2. Allele $\mathrm{T}$ and allele $\mathrm{A}$ were predominant alleles, and the genotype TT and AA frequencies were the highest in the subjects studied, respectively, in g.2264T $>\mathrm{C}$ (Table 2) and g.27676A $>C$ (Table 3). The result of the chi-squared test for g.2264T $>C$ and g. 27676A $>C$ in the populations studied indicated that the polymorphism sites were in HardyWeinberg equilibrium $(\mathrm{P}>0.05)$.

\begin{tabular}{|c|c|c|c|c|c|}
\hline \multirow[t]{2}{*}{ Groups } & \multicolumn{3}{|c|}{ Genotypic frequencies $(\mathrm{N})$} & \multicolumn{2}{|c|}{ Allelic frequencies $(\mathrm{N})$} \\
\hline & TT & $\mathrm{TC}$ & $\mathrm{CC}$ & $\mathrm{T}$ & $\mathrm{C}$ \\
\hline Case group $(\mathrm{N}=247)$ & $0.5223(129)$ & $0.3846(95)$ & $0.0931(23)$ & $0.7146(353)$ & $0.2854(141)$ \\
\hline \multirow[t]{2}{*}{ Control group $(\mathrm{N}=152)$} & $0.4868(74)$ & $0.3947(60)$ & $0.1184(18)$ & $0.6842(208)$ & $0.3158(96)$ \\
\hline & \multicolumn{3}{|c|}{$\chi^{2}=0.8432, P=0.6560$} & \multicolumn{2}{|c|}{$\chi^{2}=0.831, P=0.362$} \\
\hline
\end{tabular}

\begin{tabular}{|c|c|c|c|c|c|}
\hline \multirow[t]{2}{*}{ Groups } & \multicolumn{3}{|c|}{ Genotypic frequencies $(\mathrm{N})$} & \multicolumn{2}{|c|}{ Allelic frequencies $(\mathrm{N})$} \\
\hline & $\mathrm{AA}$ & $\mathrm{AC}$ & $\mathrm{CC}$ & A & $\mathrm{C}$ \\
\hline Case group $(\mathrm{N}=247)$ & $0.5628(139)$ & $0.3603(89)$ & $0.0769(19)$ & $0.7429(367)$ & $0.2571(127)$ \\
\hline Control group ( $N=152)$ & \multicolumn{3}{|c|}{$\chi^{2}=0.9445, P=0.6236$} & \multicolumn{2}{|c|}{$\chi^{2}=0.4892, P=0.4843$} \\
\hline
\end{tabular}




\section{Association of $O P G$ gene polymorphisms with BMD}

Age, weight, height, body mass index, spine BMD, femoral neck hip BMD, and total hip BMD in each genotype group were given as means \pm SD (Tables 4 and 5). The gene-specific SNP marker association analysis indicated a significant association of g.27676A $>C$ with spine BMD. The spine BMD of subjects with genotype AA was significantly higher than that of genotypes GA and AA (Table 5). However, no significant association was detected between any of the SNP marker genotypes and other traits measured in this study (Tables 4 and 5).

Table 4. Characteristics of the total group of subjects according to the g.2264T $>$ C genotype.
\begin{tabular}{lccc}
\hline Genotype & TT & TC & CC \\
\hline Number (\%) & $203(0.5088)$ & $155(0.3885)$ & $41(0.1028)$ \\
Age (years) & $61.8 \pm 7.5$ & $62.1 \pm 7.9$ & $62.4 \pm 6.5$ \\
Weight (kg) & $60.7 \pm 7.1$ & $61.5 \pm 6.5$ & $62.5 \pm 5.5$ \\
Height (cm) & $159 \pm 7.7$ & $160 \pm 6.6$ & $161 \pm 5.8$ \\
BMI & $23.4 \pm 3.51$ & $23.5 \pm 3.39$ & $23.7 \pm 3.43$ \\
Spine BMD $\left(\mathrm{g} / \mathrm{cm}^{2}\right)$ & $0.898 \pm 0.124$ & $0.848 \pm 0.129$ & $0.833 \pm 0.125$ \\
Femoral neck hip BMD $\left(\mathrm{g} / \mathrm{cm}^{2}\right)$ & $0.754 \pm 0.105$ & $0.696 \pm 0.109$ & $0.694 \pm 0.110$ \\
Total hip BMD $\left(\mathrm{g} / \mathrm{cm}^{2}\right)$ & $0.840 \pm 0.109$ & $0.826 \pm 0.111$ & $0.823 \pm 0.114$ \\
\hline
\end{tabular}

$\mathrm{BMI}=$ body mass index; $\mathrm{BMD}=$ bone mineral density. Data are reported as means $\pm \mathrm{SD}(\mathrm{BMD}$ values adjusted by age and weight).

Table 5. Characteristics of the total group of subjects according to the g.27676A $>$ C genotype.

\begin{tabular}{|c|c|c|c|c|}
\hline Genotype & AA & $\mathrm{AC}$ & $\mathrm{CC}$ & $P$ \\
\hline Number (\%) & $222(0.5564)$ & $142(0.3559)$ & $35(0.0877)$ & - \\
\hline Age (years) & $61.8 \pm 7.5$ & $62.6 \pm 8.1$ & $62.3 \pm 6.1$ & 0.343 \\
\hline Weight $(\mathrm{kg})$ & $61.7 \pm 7.7$ & $62.2 \pm 6.1$ & $62.3 \pm 5.5$ & 0.556 \\
\hline Height $(\mathrm{cm})$ & $159 \pm 7.4$ & $160 \pm 6.7$ & $161 \pm 6.1$ & 0.448 \\
\hline BMI & $23.5 \pm 3.48$ & $23.7 \pm 3.33$ & $23.9 \pm 3.21$ & 0.556 \\
\hline Spine BMD $\left(\mathrm{g} / \mathrm{cm}^{2}\right)$ & $0.918 \pm 0.132$ & $0.849 \pm 0.129$ & $0.831 \pm 0.121$ & 0.041 \\
\hline Femoral neck hip BMD $\left(\mathrm{g} / \mathrm{cm}^{2}\right)$ & $0.743 \pm 0.104$ & $0.697 \pm 0.107$ & $0.689 \pm 0.108$ & 0.065 \\
\hline Total hip BMD $\left(\mathrm{g} / \mathrm{cm}^{2}\right)$ & $0.844 \pm 0.111$ & $0.827 \pm 0.176$ & $0.821 \pm 0.109$ & 0.069 \\
\hline
\end{tabular}

Data are reported as means \pm SD (BMD values adjusted by age and weight). For abbreviations, see legend to Table 4.

\section{DISCUSSION}

In the present study, we investigated the role of $O P G$ in the pathogenesis of osteoporosis by association analysis. The results showed that the g.27676A $>$ C SNP polymorphism in exon 5 was associated with spine BMD in women. Subjects with genotype AA had significantly higher $\mathrm{BMD}$ compared to genotypes $\mathrm{AC}$ and $\mathrm{CC}$ (Table 5, $\mathrm{P}=0.041$ ), and the AA genotype had a higher femoral neck hip BMD and total hip BMD than genotypes AC and CC, almost reaching a significant level (Table $4, \mathrm{P}=0.065$ and $\mathrm{P}=0.069$ ). The $\mathrm{C}$ allele could be a risk factor for osteoporosis in Chinese postmenopausal women. As for g.2264T $>$ C SNP in intron 2, the TT genotype had a higher spine BMD, femoral neck hip BMD, and total hip BMD than genotypes TC and CC, almost reaching a significant level (Table 4, $\mathrm{P}=0.053, \mathrm{P}=0.061$, and $\mathrm{P}=0.072$, respectively). Although introns are not coding sequences, there is constant evidence to prove that introns play an important role in regulating mRNA splicing, transcription, and gene expression and regulation (Nott et al., 2003; Zheng et al., 2011; Yuan et al., 2012). 
Whether the detected g.2264T $>C$ locus in the $O P G$ gene intron 6 affects gene expression and regulation needs to be determined. Previous studies have found an association between several SNPs and BMD, e.g., A163G, T245G, T950C, and G1181C, which is consistent with our findings that polymorphisms in the $O P G$ gene may contribute to a genetic influence on BMD in osteoporosis (Arko et al., 2002; Langdahl et al., 2002; Ohmori et al., 2002; Jorgensen et al., 2004; Zhao et al., 2005; Kim et al., 2007; Ueland et al., 2007; Garcia-Unzueta et al., 2008; Moffett et al., 2008; Lee et al., 2010). How these polymorphisms affect BMD still remains poorly understood. Further studies are necessary to elucidate the underlying molecular mechanism and pathophysiology.

\section{REFERENCES}

Albagha OM and Ralston SH (2006). Genetics and osteoporosis. Rheum. Dis. Clin. North Am. 32: 659-680.

Arko B, Prezelj J, Komel R, Kocijancic A, et al. (2002). Sequence variations in the osteoprotegerin gene promoter in patients with postmenopausal osteoporosis. J. Clin. Endocrinol. Metab. 87: 4080-4084.

Arko B, Prezelj J, Kocijancic A, Komel R, et al. (2005). Association of the osteoprotegerin gene polymorphisms with bone mineral density in postmenopausal women. Maturitas 51: 270-279.

Cheung CL, Xiao SM and Kung AW (2010). Genetic epidemiology of age-related osteoporosis and its clinical applications. Nat. Rev. Rheumatol. 6: 507-517.

Cummings SR, Kelsey JL, Nevitt MC and O’Dowd KJ (1985). Epidemiology of osteoporosis and osteoporotic fractures. Epidemiol. Rev. 7: 178-208.

Fang Y, van Meurs JB, d'Alesio A, Jhamai M, et al. (2005). Promoter and 3'-untranslated-region haplotypes in the vitamin d receptor gene predispose to osteoporotic fracture: the rotterdam study. Am. J. Hum. Genet. 77: 807-823.

Ferrari S (2008). Human genetics of osteoporosis. Best. Pract. Res. Clin. Endocrinol. Metab. 22: 723-735.

Garcia-Unzueta MT, Riancho JA, Zarrabeitia MT, Sanudo C, et al. (2008). Association of the $163 \mathrm{~A} / \mathrm{G}$ and 1181G/C osteoprotegerin polymorphism with bone mineral density. Horm. Metab. Res. 40: 219-224.

Geng L, Yao Z, Yang H, Luo J, et al. (2007). Association of CA repeat polymorphism in estrogen receptor beta gene with postmenopausal osteoporosis in Chinese. J. Genet. Genomics 34: 868-876.

Gennari L, Merlotti D, De Paola V, Calabro A, et al. (2005). Estrogen receptor gene polymorphisms and the genetics of osteoporosis: a HuGE review. Am. J. Epidemiol. 161: 307-320.

Hofbauer LC and Schoppet M (2002). Osteoprotegerin gene polymorphism and the risk of osteoporosis and vascular disease. J. Clin. Endocrinol. Metab. 87: 4078-4079.

Hosoi T (2010). Genetic aspects of osteoporosis. J. Bone Miner. Metab. 28: 601-607.

Ioannidis JP, Stavrou I, Trikalinos TA, Zois C, et al. (2002). Association of polymorphisms of the estrogen receptor alpha gene with bone mineral density and fracture risk in women: a meta-analysis. J. Bone Miner. Res. 17: 2048-2060.

Ioannidis JP, Ralston SH, Bennett ST, Brandi ML, et al. (2004). Differential genetic effects of ESR1 gene polymorphisms on osteoporosis outcomes. JAMA 292: 2105-2114.

Jorgensen HL, Kusk P, Madsen B, Fenger M, et al. (2004). Serum osteoprotegerin (OPG) and the A163G polymorphism in the OPG promoter region are related to peripheral measures of bone mass and fracture odds ratios. J. Bone Miner. Metab. 22: 132-138.

Kanis JA, Melton LJ, III, Christiansen C, Johnston CC, et al. (1994). The diagnosis of osteoporosis. J. Bone Miner. Res. 9: 1137-1141.

Kim JG, Kim JH, Kim JY, Ku SY, et al. (2007). Association between osteoprotegerin (OPG), receptor activator of nuclear factor-kappaB (RANK), and RANK ligand (RANKL) gene polymorphisms and circulating OPG, soluble RANKL levels, and bone mineral density in Korean postmenopausal women. Menopause 14: 913-918.

Langdahl BL, Carstens M, Stenkjaer L and Eriksen EF (2002). Polymorphisms in the osteoprotegerin gene are associated with osteoporotic fractures. J. Bone Miner. Res. 17: 1245-1255.

Lee YH, Woo JH, Choi SJ, Ji JD, et al. (2010). Associations between osteoprotegerin polymorphisms and bone mineral density: a meta-analysis. Mol. Biol. Rep. 37: 227-234.

Li Y, Xi B, Li K and Wang C (2012). Association between vitamin D receptor gene polymorphisms and bone mineral density in Chinese women. Mol. Biol. Rep. 39: 5709-5717.

Mann V and Ralston SH (2003). Meta-analysis of COL1A1 Sp1 polymorphism in relation to bone mineral density and osteoporotic fracture. Bone 32: 711-717. 
Moffett SP, Oakley JI, Cauley JA, Lui LY, et al. (2008). Osteoprotegerin Lys3Asn polymorphism and the risk of fracture in older women. J. Clin. Endocrinol. Metab. 93: 2002-2008.

Nott A, Meislin SH and Moore MJ (2003). A quantitative analysis of intron effects on mammalian gene expression. RNA 9: 607-617.

Ohmori H, Makita Y, Funamizu M, Hirooka K, et al. (2002). Linkage and association analyses of the osteoprotegerin gene locus with human osteoporosis. J. Hum. Genet. 47: 400-406.

Peck WA (1993). Consensus development conference: diagnosis, prophylaxis, and treatment of osteoporosis. Am. J. Med. 94: 646-650.

Pocock NA, Eisman JA, Hopper JL, Yeates MG, et al. (1987). Genetic determinants of bone mass in adults. A twin study. J. Clin. Invest. 80: 706-710.

Ralston SH (2010). Genetics of osteoporosis. Ann. N. Y. Acad. Sci. 1192: 181-189.

Riggs BL and Melton LJ, III (1986). Involutional osteoporosis. N. Engl. J. Med. 314: 1676-1686.

Ueland T, Bollerslev J, Wilson SG, Dick IM, et al. (2007). No associations between OPG gene polymorphisms or serum levels and measures of osteoporosis in elderly Australian women. Bone 40: 175-181.

Vidal C, Formosa R and Xuereb-Anastasi A (2011). Functional polymorphisms within the TNFRSF11B (osteoprotegerin) gene increase the risk for low bone mineral density. J. Mol. Endocrinol. 47: 327-333.

Yamada Y (2001). Association of polymorphisms of the transforming growth factor-betal gene with genetic susceptibility to osteoporosis. Pharmacogenetics 11: 765-771.

Yamada Y, Ando F, Niino N and Shimokata H (2003). Association of polymorphisms of the osteoprotegerin gene with bone mineral density in Japanese women but not men. Mol. Genet. Metab. 80: 344-349.

Yuan Z, Chu G, Dan Y, Li J, et al. (2012). BRCA1: a new candidate gene for bovine mastitis and its association analysis between single nucleotide polymorphisms and milk somatic cell score. Mol. Biol. Rep. 39: 6625-6631.

Zhao HY, Liu JM, Ning G, Zhao YJ, et al. (2005). The influence of Lys3Asn polymorphism in the osteoprotegerin gene on bone mineral density in Chinese postmenopausal women. Osteoporos. Int. 16: 1519-1524.

Zheng X, Ju Z, Wang J, Li Q, et al. (2011). Single nucleotide polymorphisms, haplotypes and combined genotypes of LAP3 gene in bovine and their association with milk production traits. Mol. Biol. Rep. 38: 4053-4061. 